Clinical and Experimental Surgery

Founded 1969

Editor-in-Chief

K. Messmer, Heidelberg

\section{Editorial Board}

J. Ahonen, Helsinki

H.G. Beger, Ulm

R. Benichoux, Luneville

H. Bismuth, Villejuif

S.-E. Bergentz, Malmö

J.L. Berk, Cleveland, Ohio

R.Y. Calne, Cambridge

R. Dionigi, Pavia

U. Haglund, Malmö

R.O. Heimbecker,

Collingwood, Ont.
W.P. Klövekorn, Munich

F. Largiadèr, Zurich

M. Lempinen, Helsinki

D. Loisance, Créteil

R. Lozano, Zaragoza

H.E. Myrvold, Trondheim

R. Schosser, Heidelberg

I. Taylor, Southampton

R.E. Wilson, Boston, Mass. 
No. 1 Original Papers

Peritoneal Lavage Efficiently Eliminates Protease-Alpha-2-Macroglobulin Complexes and Components of the Contact System from the Peritoneal Cavity in Patients with Severe Acute Pancreatitis

Aasen, A.O.; Ruud, T.E.; Roeise, O.; Bouma, B.N.; Stadaas, J.O. . . . . . . . . . . .

Inhibition of Proteinases with Recombinant Eglin C during Experimental Escherichia coli Septicemia in the Pig

Siebeck, M.; Hoffmann, H.; Jochum, M.; Fritz, H.

Improved Survival with Splenic Autotransplantation and Fibronectin Therapy following Endotoxin Administration in Rats

Calise, F.; Capron-Laudereau, M.; Gugenheim, J.; Pin, M.-L.; Gigou, M.; Cuomo, O.; Reynes, M.; Bismuth, H. . . . . . . . . . . . . . . . . . . .

Magnetic Resonance Imaging in Detecting Acute Oedematous and Haemorrhagic Pancreatitis: An Experimental Study in Pigs

Puolakkainen, P.; Kivisaari, L.; Sipponen, J.; Standertskjöld-Nordenstam, C.-G.; Nuutinen, P.; Schöder, T. . . . . . . . . . . . . . . . . . . . .

Studies on the Dose Dependence of Endotoxin-Induced in vitro Activation of the Complement System

Roeise, O.; Garred, P.; Mollnes, T.E.; Aasen, A.O.

Acute Ischemic Liver Failure in the Rat: A Reproducible Model Not Requiring Portal Decompression

Asakawa, H.; Jeppsson, B.; Mack, P.; Hultberg, B.; Hägerstrand, I.; Bengmark, S. . Effects of Hyperthermochemoradiotherapy on KSE-1 Cells, a Newly Established Human Squamous Cell Line Derived from Esophageal Carcinoma

Matsuoka, H.; Sugimachi, K.; Mori, M.; Kuwano, H.; Ohno, S.; Nakano, S. . . . . . . Autogenous Skin and Fascia Grafts as Topical Hemostatic Agents in Splenic Injuries

Eitan, A.; Munichor, M.; Barzilai, A. . . . . . . . . . . . . . . .

\section{No. 2 Original Papers}

Long-Term Survival of Kidney Allografts in Dogs after Withdrawal of Immunosuppression with Ciclosporin and Azathioprine

Davies, ff. S.H.; St. John Collier, D.; Thiru, S.; Decurtins, M.; Calne, R.Y. . . . . . .

Restoration of ATP Contents in the Transplanted Liver Closely Relates to Graft Viability in Dogs

Higashi, H.; Takenaka, K.; Fukuzawa, K.; Yoshida, Y.; Sugimachi, K. . . . . . . . 76 
Thioacetamide- and Carbon Tetrachloride-Induced Liver Cirrhosis

Dashti, H.; Jeppsson, B.; Hägerstrand, I.; Hultberg, B.; Srinivas, U.; Abdulla, M.; Beng-

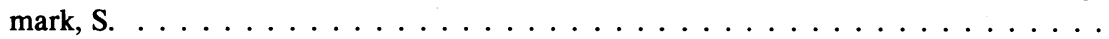

New Intraoperative Biliary Manometric Technique Using a Balloon Catheter - Selective Evaluation of Papillary Function

Kubota, K.; Itoh, T.; Shibayama, K.; Kosuge, T.; Nomura, Y.; Idezuki, Y. . . . . . . .

Effects of Partial Deprivation of Portal Blood on Arterial Blood Ketone Body Ratio in Rabbits

Yamamoto, S.; Nitta, N.; Kamiyama, Y.; Yamaoka, Y.; Ozawa, K. . . . . . . . . . .

Primate Cardiac Allo- and Xenotransplantation: Modulation of the Immune Response with Photochemotherapy

Pepino, P.; Berger, C.L.; Fuzesi, L.; Panza, A.; Pierson, R.N.; Gutierrez, C.; Marboe, C.C.; Smith, C.R.; Reemtsma, K.; Rose, E.A. . . . . . . . . . . . . . . .

Blood Mononuclear Cell Production of IL-1 and IL-2 following Moderate Surgical Trauma

Grzelak, I.; Olszewski, W.L.; Rowinski, W.

Coronary Artery Plaque Rapidly Induced by Local Electromagnetic Stimulation in the Baboon

Breuer, H.; Fincham, J.; Hinrichsen, P.; Uys, C.J.; Weich, H.; Reichart, B.

\section{No. 3-4 Original Papers}

Disturbances of Reticulo-Endothelial Function following Experimental Liver Transplantation

Lahnborg, G.; Bracher, M.; Hickman, R.; Terblanche, J.

Orthotopic Partial Liver Transplantation in Dogs Can Be Performed without Cold Perfusion of the Donor Liver. Evaluation of Its Feasibility in Terms of Energy Metabolism

Tokunaga, Y.; Zaima, M.; Tanaka, K.; Maki, A.; Katayama, T.; Sakai, Y.; Egawa, H.; Kiuchi, T.; Yamamoto, Y.; Ueda, J.; Lin, H.; Kitakado, Y.; Nitta, N.; Kamiyama, Y.; Yamaoka, Y.; Ozawa, K. . . . . . . . . . . . . . . . . .

Changes in Serum Bile Acid Composition in Relation to Histological Findings after Liver Transplantation in Piglets

Okanoue, T.; Kimoto, M.; Maki, A.; Usui, Y.; Nishimura, N.; Kobayashi, N.; Kamiyama, Y.; Ozawa, K. . . . . . . . . . . . . . . . . . . .

Use of Verapamil with Conventional Immunosuppression after Porcine Renal Transplantation

Kahn, D.; Hickman, R.; Dreyer, C.; Temple Camp, C. . . . . . . . . . . . . . . . .

Pancreaticoduodenal Graft in the Rat: An Original Microsurgical Technique

Benetti, L.; Bassi, C.; Zamboni, G.; Radin, S.; Falconi, M.; Girelli, R.; Elio, A.; Briani, G.F.; Cavallini, G.; Pederzoli, P. . . . . . . . . . . . . . . . . . . . . 162

Pressure-Volume Curve of the Remaining Lung after Lung Resection

Hatakeyama, S.; Harada, K.; Saoyama, N.; Monden, Y.

Morphological and Hemodynamic Changes of the Lung after Injection of 5\% Ethanolamine Oleate into Dogs

Iso, Y.; Kitano, S.; Iwanaga, T.; Hashizume, M.; Sugimachi, K. . . . . . . . . . . . . 175

1,2-Dimethylhydrazine-Induced Carcinogenesis Influenced by Different Colonic Anastomoses in Rats

Rokitansky, A.; Trubel, W.; Buxbaum, P.; Moeschl, P. 
Famotidine Does Not Inhibit Liver Regeneration

Kanashima, R.; Kobayashi, M.

Effect of Preoperative 4'-Epidoxorubicin (Epi-Adriamycin) Treatment on the Regeneration and Function of the Liver in Partially Hepatectomized Rats

Hall, K.S.; Lien, B.; Paulsen, J.E.; Clausen, O.P.F.; Bergan, A.; Rugstad, H.E.

Analysis of Hemodynamics and Blood Gas in Relation to Blood Ketone Body Ratio in Partially Hepatectomized Patients

Nakatani, T.; Shimahara, Y.; Mori, K.; Kobayashi, N.; Yamaoka, Y.; Kobayashi, K.;

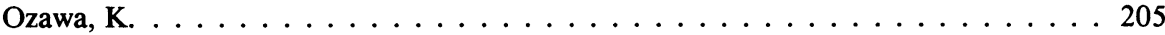

Effect of $\mathbf{P G I}_{2}$ and Thromboxane Antagonist on Liver Ischemic Injury

Besse, T.; Gustin, T.; Claeys, N.; Schroeyers, P.; Lambotte, L. . . . . . . . . . . . . . . 213

Revised Model for the Study of Colonic Anastomotic Healing in Protein Malnourished Rats

Law, N.W.; Ellis, H.

Hypoxia Enhances the Lethality of Mitomycin C and Carboquone against Human Malignant Tumor Cells in vitro

Kusumoto, T.; Maehara, Y.; Sakaguchi, Y.; Saku, M.; Sugimachi, K. . . . . . . . . . . 224

Announcements

No. 5 Obituary

Walter Brendel . . . . . . . . . . . . . . . . . . . . . 233

Original Papers

Immunological Treatment with Low Dosage Ciclosporin in Rat Liver Allotransplantation

Okamura, R.; Tanaka, K.; Asonuma, K.; Uemoto, S.; Katayama, T.; Tanaka, M.; Utsunomiya, H.; Ozawa, K.; Hoshida, T.; Inui, K.; Hori, R. . . . . . . . . . . . . . . 235

Effect of Hyperthermia on Isolated Perfused Rat Liver Zavagno, G.; Vespa, D.; Moschin, N.; Belluco, C.; Cecchetto, A.; Bertocco, E.; Raimondo, A.; Lise, $M$

Extent of Hepatectomy in the Rat. Evaluation of Basal Conditions and Effect of Therapy Emond, J.; Capron-Laudereau, M.; Meriggi, F.; Bernuau, J.; Reynes, M.; Houssin, D. 251 Interleukin-2 and Alpha Interferon Therapy of Advanced Pulmonary Metastases

Kim, B.; Warnaka, P.; Imbembo, A. . . . . . . . . . . . . . . . . . . . . . . 260

Preventing Recurrent Postoperative Adhesions: An Experimental Study in Rats Verreet, P.R.; Fakir, C.; Ohmann, C.; Röhrer, H.D. . . . . . . . . . . . . . . . . . 267

Comparison of Cardiopulmonary Variables with Intermittent Positive Pressure Ventilation and High-Frequency Jet Ventilation during Abdominal Aortic Operations

Tabatabai, M.; Javadi, P.P. . . . . . . . . . . . . . . . . . . . . . . . 274

Carbon Tetrachloride-Induced Experimental Cirrhosis in the Rat: A Reappraisal of the Model

Ariosto, F.; Riggio, O.; Cantafora, A.; Colucci, S.; Gaudio, E.; Mechelli, C.; Merli, M.; Seri, S.; Capocaccia, L. . . . . . . . . . . . . . . . . . . . . . . 280

Inhibition of Thrombin on Subendothelium. Studies on Rabbit Aorta, ex vivo

Nydahl, S.; Frebelius, S.; Swedenborg, J.

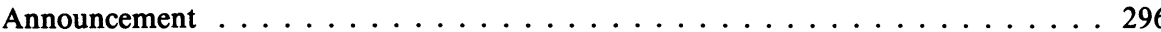




\section{No. 6 Original Papers}

Oxygen Free Radical-Induced Histamine Release during Intestinal Ischemia and Reperfusion Boros, M.; Kaszaki, J.; Nagy, S. . . . . . . . . . . . . . . . . . . . . . . 297

Piroxicam Affects Collagen Changes around Experimental Intestinal Anastomoses

Mastboom, W.J.B.; Hendriks, T.; Elteren, P. van; Boer, H.H.M. de . . . . . . . . . . . 305

Multifocal Gastric Cancer in Patients Younger than 50 Years of Age

Furukawa, H.; Iwanaga, T.; Imaoka, S.; Hiratsuka, M.; Fukuda, I.; Kabuto, T.; Ishikawa, O.; Sasaki, Y.

Model of Pulmonary Extravasation as an Effect of Neutropenia in Endotoxic Shock in Guinea Pigs

Mårtensson, L.; Davidsson, B.; Hultkvist, U. . . . . . . . . . . . . . . . . . . . 319

Hemodynamic Effects of Mexiletine and Disopyramide after Cardioplegic Arrest

Moritz, A.; Eckersberger, F.; Losert, U.; Probst, P.; Schreiner, W.; Wolner, E. . . . 327

Serial Mixed Lymphocyte Culture Responses in Pigs after Liver or Kidney Auto- or Allotransplantation

Bracher, M.; Hickman, R.; Terblanche, J.

Rib Fracture Healing after Osteosynthesis with Wire Mesh Titanium and Screws:

A Histological Study in Sheep

Klein, C.P.A.T.; Lubbe, H.B.M. van der; Gahr, R.H. . . . . . . . . . . . . . . . . 347

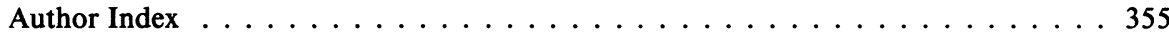

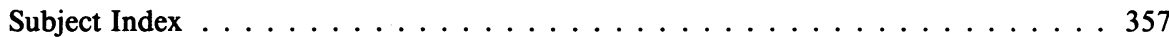

Suppl. 1 Long Acting Cephalosporins in Surgery

World Congress of the International College of Surgeons

Milan, July 3-9, 1988

Guest Editor: K. Hell, Basel

Suppl. 2 European Society for Surgical Research

24th Congress, Brussels 1989

Abstracts

Editors: B. de Hemptinne, Brussels; S. Karran, Southampton; L. Lambotte, Brussels 


\title{
Inhibition of Proteinases with Recombinant Eglin C during Experimental Escherichia coli Septicemia in the Pig
}

\author{
M. Siebeck ${ }^{\mathrm{a}}$, H. Hoffmann ${ }^{\mathrm{a}}$, M. Jochum ${ }^{\mathrm{b}}$, H. Fritz ${ }^{\mathrm{b}}$ \\ ${ }^{a}$ Chirurgische Klinik Innenstadt und Chirurgische Poliklinik, und \\ ${ }^{b}$ Abteilung für Klinische Chemie und Klinische Biochemie in der Chirurgischen Klinik Innenstadt, \\ Ludwig-Maximilians-Universität München, BRD
}

Key Words. Septic shock - Escherichia coli $\cdot$ Pigs $\cdot$ Neutrophil elastase $\cdot$ Eglin C . Proteinase inhibitors · Vascular permeability

Abstract. Administration of the proteinase inhibitor eglin $\mathrm{C}$ reduces the symptoms of capillary leakage in a porcine model of septic shock. This was assessed by measurements of blood pressure, plasma protein concentration, hematocrit, and duration of urine production. Eglin C plasma levels around $1.2 \mu M$ resulted from a dose of $1.9 \mathrm{mg} \cdot \mathrm{kg}^{-1} \cdot \mathrm{h}^{-1}$ for $4 \mathrm{~h}$ and were therapeutically effective. A higher dose of eglin $C\left(7.7 \mathrm{mg} \cdot \mathrm{kg}^{-1} \cdot \mathrm{h}^{-1}\right.$ for $\left.4 \mathrm{~h}\right)$ induced levels of approximately $5.6 \mu \mathrm{M}$ in plasma and was not superior. This observation indicates that lysosomal proteases from neutrophils or degranulation of mast cells play a crucial role in the increase of capillary permeability during septicemia.

\section{Introduction}

Eglin $\mathrm{C}$ is a protein proteinase inhibitor originally derived from the medical leech [10]. It contains 70 amino acid residues in a single polypeptide chain without disulfide bridges and its relative molecular weight is 8,100 . It is a rapid and potent inhibitor of human granulocytic elastase, cathepsin G, and chymotrypsin, and it is unusually stable against denaturation by heat, acid, and proteolysis.

In a previous study, we examined possible pathophysiologic mechanisms in septic shock which may be initiated by lysosomal proteinases released into the extracellular space [4] using r-eglin $C$ in a dose of 3.85 $\mathrm{mg} \cdot \mathrm{kg}^{-1} \cdot \mathrm{h}^{-1}$. The present study was conducted to determine the effect of a higher (2-fold increased) and a lower (50\% reduced) dose of r-eglin $\mathrm{C}$ on experimental septicemia in a similar model of septic shock.

\section{Materials and Methods}

A synthetic gene coding for the sequence of eglin $C$ was expressed in transformed Escherichia coli and the expression product, recombinant eglin $C$ (r-eglin C) was purified [9]. r-Eglin C was found to possess the same inhibitory properties as the natural protein from the leech.

Weaned domestic pigs were purchased from the Lehr- und Versuchsgut Oberschleissheim, Veterinary 
School, University of Munich. The experiments were performed with 18 pigs with body weights ranging from 17 to $25.5 \mathrm{~kg}$ (mean: $19.7 \mathrm{~kg}$ ). Acepromazine maleate, $50 \mathrm{mg}$, was given intramuscularly for premedication after fasting overnight and anesthesia was induced with pentobarbital, $15 \mathrm{mg} / \mathrm{kg}$, given intravenously. Narcosis was maintained by repeated injections of pentobarbital, $80 \mathrm{mg}$, as needed. Pentobarbital injection was avoided during the 10 min preceding aortic blood pressure measurements.

Left groin vessels were cannulated with salinefilled polyethylene catheters. The blood pressure in the aorta was measured with a Bentley Trantec Model 800 transducer and a Siemens Sirecust 404 monitor. Two femoral venous lines were used for infusions. Blood was sampled with a short, large bore cannula in the left external jugular vein. A suprapubic cystostomy was performed to enable collection of urine. The animals were allowed to rest for $60 \mathrm{~min}$ after the operation and remained in the right lateral position during the experiment. They were breathing spontaneously room air.

All animals received a suspension of freshly cultured E. coli ( $014 \mathrm{~B} 26), 3 \cdot 10^{10}$ cells, as assessed by turbidimetry, in $24 \mathrm{ml}$ saline over $2 \mathrm{~h}$. Each animal was randomly assigned to 1 of 3 treatment protocols: 6 animals received $E$. coli and $0.9 \%$ saline, $200 \mathrm{ml}$, and served as controls; 6 animals were given $E$. coli and a 'low' dose of r-eglin C, $1.9 \mathrm{mg} \cdot \mathrm{kg}^{-1} \cdot \mathrm{h}^{-1}$; and 6 animals $E$. coli and a 'high' dose of r-eglin C, 7.7 $\mathrm{mg} \cdot \mathrm{kg}^{-1} \cdot \mathrm{h}^{-1}$. The r-eglin C (or saline) infusion was started simultaneously with the $E$. coli infusion (time zero) and was given for $4 \mathrm{~h}$ in a volume of $200 \mathrm{ml}$.

The output of urine was measured hourly. Anuria was diagnosed when the urine production fell below $3 \mathrm{ml} / \mathrm{h}$. Survival periods and duration of urine production were calculated from time zero. The experiments were terminated $24 \mathrm{~h}$ after time zero if death due to septic shock was not imminent. Plasma samples were made as follows: blood was anticoagulated with $3.8 \%$ citrate $1: 10$ and centrifuged at $4{ }^{\circ} \mathrm{C}$ at $3,000 \mathrm{rpm}$ for $20 \mathrm{~min}$. The supernatant was aliquoted and stored at $-80^{\circ} \mathrm{C}$. Arterial blood gas analyses were performed with an AVL Gas Check 939 on heparinized samples. Blood for cell counts was anticoagulated with EDTA. Hematocrit was measured with microcapillaries and a Hettich Hämatokrit centrifuge, hemoglobin was measured with a Coulter Haemoglobinometer, white blood cells were counted with a Coulter Counter Model D, and platelets in a Neu-

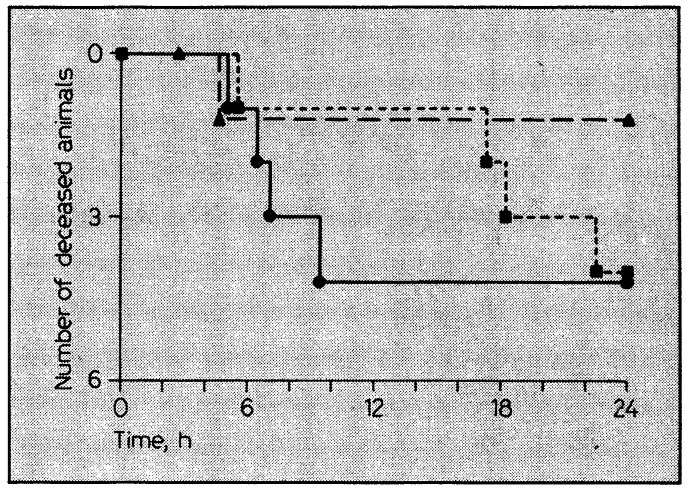

Fig. 1. Cumulative mortality after E. coli and reglin $C$ administration ( $n=6$ in each group).

E. coli, $3 \cdot 10^{10}$ cells $+\mathrm{NaCl}, 0.9 \%$ (control group) $(\bullet \bullet)$ ). E. coli, $3 \cdot 10^{10}$ cells $+\mathrm{r}$-eglin C, $1.9 \mathrm{mg} \cdot \mathrm{kg}^{-1} \cdot \mathrm{h}^{-1}(\mathbf{\Lambda}-\mathbf{- \Lambda})$. E. coli, $3 \cdot 10^{10}$ cells $+\mathrm{r}$-eglin C, $7.7 \mathrm{mg} \cdot \mathrm{kg}^{-1} \cdot \mathrm{h}^{-1}(\mathbf{\omega}----\mathbf{})$.

bauer hemocytometer chamber. r-Eglin $\mathrm{C}$ concentrations in plasma were quantitated by a competitive enzyme-linked immunosorbent assay [8] using peroxidase-conjugated eglin and affinity purified antibodies from sheep directed against leech eglin [Müller-Esterl et al., unpubl. results]. The total protein concentration in plasma was measured by the Biuret method. Creatinine in plasma was measured kinetically on an automated analyzer using picric acid (Merck, Darmstadt).

All data are presented as arithmetic mean \pm sample standard deviation. Survival curves for the events death and anuria were analyzed with the generalized Mantel-Haenszel test followed by Scheffé type multiple comparisons $(\alpha=0.05)$. All other parameters were compared using a one-way analysis of variance followed by Scheffe's multiple comparison test with $\alpha=$ 0.05 . For statistical significance testing we selected the time $4 \mathrm{~h}$ after start of the infusions for two reasons: the eglin infusions were discontinued after $4 \mathrm{~h}$, and the case numbers in the three groups declined thereafter due to mortality from septicemia. Since there was considerable variation of the hematocrit starting values between the three groups we selected the hourly rate of increase of hematocrit of each individual animal during the first $4 \mathrm{~h}$, as assessed by linear regression over time, as a measure of hemoconcentration. 


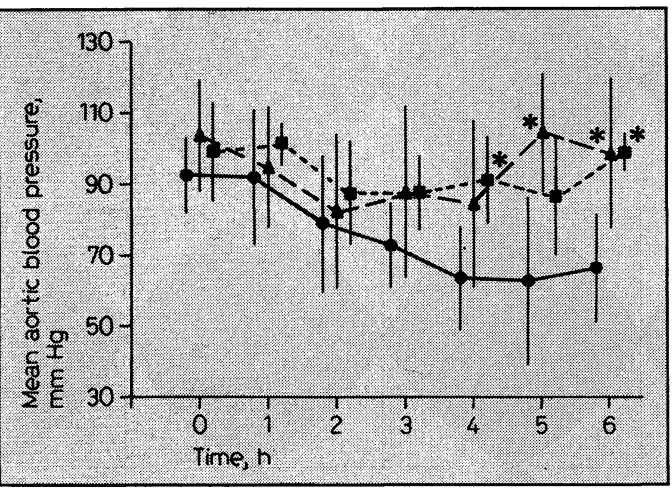

Fig. 2. Mean aortic pressure after E.coli and r-eglin $C$ administration. Means and standard deviation. Asterisk indicates a significant $(p<0.05)$ difference from the control group ( $n=6$ in each group).

E. coli, $3 \cdot 10^{10}$ cells $+\mathrm{NaCl}, 0.9 \%$ (control group) $(\bullet-)$ ). E. coli, $3 \cdot 10^{10}$ cells $+\mathrm{r}$-eglin C, $1.9 \mathrm{mg} \cdot \mathrm{kg}^{-1} \cdot \mathrm{h}^{-1}(\mathbf{\Lambda}--\mathbf{\Delta})$. E. coli, $3 \cdot 10^{10}$ cells + r-eglin C, $7.7 \mathrm{mg} \cdot \mathrm{kg}^{-1} \cdot \mathrm{h}^{-1}(\mathrm{m----})$ ).

\section{Results}

\section{Mortality (fig. 1)}

One animal that had received E. coli and r-eglin $\mathrm{C}$ in the low dose, $1.9 \mathrm{mg} \cdot \mathrm{kg}^{-1} \cdot \mathrm{h}^{-1}$ for $4 \mathrm{~h}$, died after $2 \mathrm{~h} 40 \mathrm{~min}$ of nonseptic cardiac failure and was eliminated thereafter from anuria analysis. Total mortality due to septicemia was $9 / 17$ (ㅇ 53\%). The 24-hour survival rate was $2 / 6$ in the septic reference group, $4 / 5$ in the low-dose and $2 / 6$ in the high-dose eglin group.

\section{Arterial Hypotension (fig. 2)}

In nearly all animals a marked reduction in mean arterial blood pressure was observed at the end of the $E$. coli infusion. All animals of the septic reference group had a severe hypotension (a fall in mean aortic pressure by more than $25 \mathrm{~mm} \mathrm{Hg}$ ) during the first $4 \mathrm{~h}$. Two animals of the low-dose eglin group and

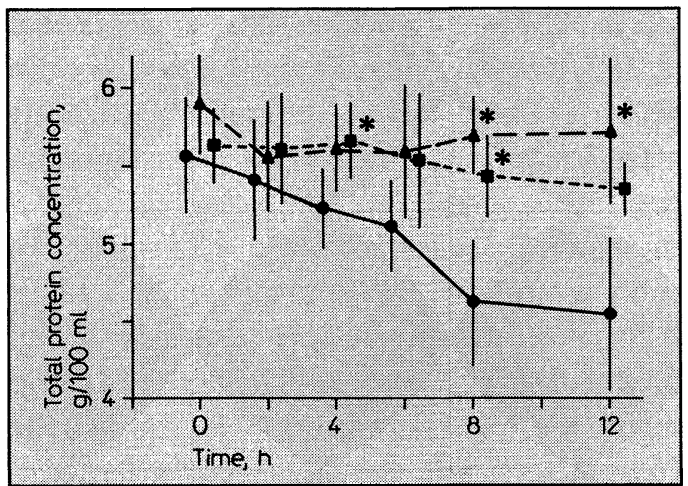

Fig. 3. Total protein concentration in plasma after $E$. coli and r-eglin C administration. Means and standard deviation. Asterisk indicates a significant $(p<$ $0.05)$ difference from the control group ( $n=6$ in each group).

E. coli, $3 \cdot 10^{10}$ cells $+\mathrm{NaCl}, 0.9 \%$ (control group) $(\bullet \longrightarrow)$. E. coli, $3 \cdot 10^{10}$ cells $+\mathrm{r}$-eglin C, $1.9 \mathrm{mg} \cdot \mathrm{kg}^{-1} \cdot \mathrm{h}^{-1}(\mathbf{\Delta}-\mathbf{- \Delta})$. E. coli, $3 \cdot 10^{10}$ cells $+\mathrm{r}$-eglin $\mathrm{C}, 7.7 \mathrm{mg} \cdot \mathrm{kg}^{-1} \cdot \mathrm{h}^{-1}(\mathbf{\square - - - - \square )}$.

4 pigs of the high-dose group did not show this response. In the surviving animals, a recovery of blood pressure was noted, in some of them even exceeding the starting value. Group means differed significantly after $4 \mathrm{~h}$ with the blood pressure in the septic reference group being $20-30 \mathrm{~mm} \mathrm{Hg}$ lower than in the two eglin groups (in the control group $63.5 \pm 14.7 \mathrm{~mm} \mathrm{Hg}$, in the low-dose group $84.6 \pm 23.7 \mathrm{~mm} \mathrm{Hg}$, and $91.2 \pm 12.5$ $\mathrm{mm} \mathrm{Hg}$ in the high-dose group). In the Scheffé comparison only the high dose group differed significantly from the control group.

\section{Hypoproteinemia (fig. 3)}

The total plasma protein concentration decreased steadily in the septic reference group from $5.6 \pm 0.4$ to $4.6 \pm 0.5 \mathrm{~g} / 100 \mathrm{ml}$, whereas it remained more or less constant in both eglin groups (slight decrease from $5.9 \pm$ 
0.3 to $5.7 \pm 0.5$ in the low-dose and from 5.6 \pm 0.2 to $5.4 \pm 0.2$ in the high-dose eglin group). Group means differed significantly after $4 \mathrm{~h}$ with the total plasma protein concentration in the septic reference group being about $0.4 \mathrm{~g} / 100 \mathrm{ml}$ lower than in the two eglin groups (in the control group $5.23 \pm$ $0.26 \mathrm{~g} / 100 \mathrm{ml}$, in the low-dose eglin group $5.62 \pm 0.28 \mathrm{~g} / 100 \mathrm{ml}$, and $5.67 \pm 0.24 \mathrm{~g} / 100$ $\mathrm{ml}$ in the high dose group). In the Scheffé comparison only the high-dose group differed significantly from the control group.

\section{Hemoconcentration (fig. 4)}

Hematocrit increased rapidly (from $30 \pm$ 3 to $38 \pm 3 \%$ ) during the first $4 \mathrm{~h}$ in the septic reference animals. The rise was less pronounced under eglin administration (from $32 \pm 4$ to $36 \pm 4 \%$ ). In the septic reference animals, the hemoconcentration expressed as the mean rate of rise of hematocrit during the first $4 \mathrm{~h}$ by linear regression over time was $1.5 \pm 0.9 \%$ per hour as opposed to $0.7 \pm 0.5 \%$ per hour in all eglintreated animals. The hemoglobin concentrations behaved similarly.

\section{Renal Function}

Figure 5 shows a life table plot for the time intervals between time zero and the onset of anuria for the three groups, After $24 \mathrm{~h}$, only 6 of all animals ( $\hat{=} 35 \%$ ) were not anuric: $1 / 6(\hat{=} 17 \%)$ of the septic reference animals but $3 / 5(\hat{=} 60 \%)$ and $2 / 6(\hat{=} 33 \%)$ of the low- and high-dose eglin-treated pigs, respectively. The difference between the three groups was not significant. When data from both eglin groups were pooled renal function was significantly protected $(\mathrm{p}=$ 0.048 ) when compared to the septic reference animals by the generalized MantelHaenszel test. Creatinine concentration in

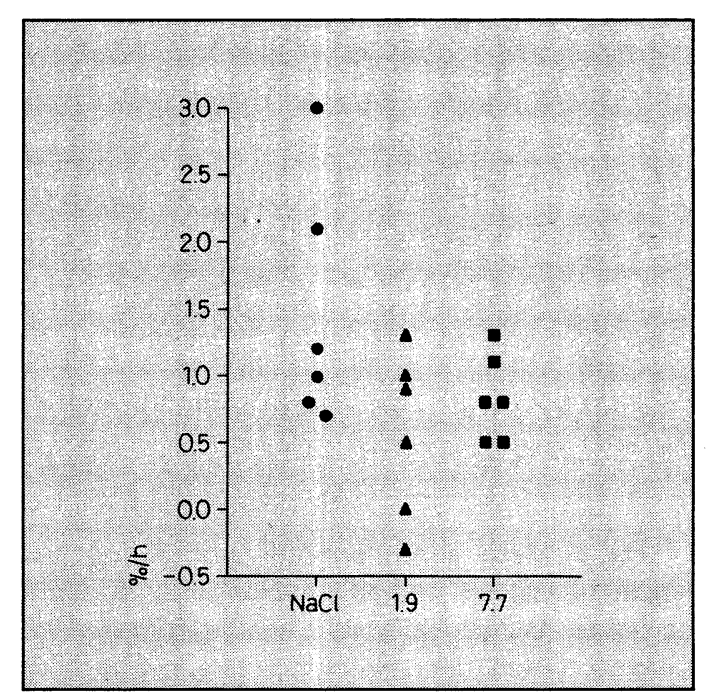

Fig. 4. Hemoconcentration during the first $4 \mathrm{~h}$ of E. coli and r-eglin $\mathrm{C}$ administration. Abscissa $=\mathrm{Ex}-$ perimental groups; ordinate $=$ hourly rise of hematocrit by linear regression over time $(\% / h)(n=6$ in each group).

E. coli, $3 \cdot 10^{10}$ cells $+\mathrm{NaCl}, 0.9 \%$ (control group) (๑).

E. coli, $3 \cdot 10^{10}$ cells $+\mathrm{r}$-eglin C, $1.9 \mathrm{mg} \cdot \mathrm{kg}^{-1} \cdot \mathrm{h}^{-1}(\mathbf{\Delta})$.

E. coli, $3 \cdot 10^{10}$ cells $+\mathrm{r}$-eglin C, $7.7 \mathrm{mg} \cdot \mathrm{kg}^{-1} \cdot \mathrm{h}^{-1}(\boldsymbol{(})$.

plasma increased from $1.06 \pm 0.22 \mathrm{mg} / 100$ $\mathrm{ml}$ at time zero to $2.6 \pm 1.6 \mathrm{mg} / 100 \mathrm{ml}$ (last available value for each animal). Plasma creatinine concentration was noticeably higher in controls than in the other groups after $6 \mathrm{~h}$ $(1.2 \pm 0.34 \mathrm{mg} / 100 \mathrm{ml}$ in the low-dose group and $1.26 \pm 0.26 \mathrm{mg} / 100 \mathrm{ml}$ in the high-dose group as compared to $1.78 \pm 0.29 \mathrm{mg} / 100$ $\mathrm{ml}$ in the control group) and later on.

\section{Eglin C Plasma Levels (fig. 6)}

Maximum eglin $C$ plasma levels were 9.6 $\pm 1.3 \mu \mathrm{g} / \mathrm{ml}(\triangleq 1.2 \mu M)$ after $4 \mathrm{~h}$ of lowdose eglin $\mathrm{C}$ infusion, $1.9 \mathrm{mg} \cdot \mathrm{kg}^{-1} \cdot \mathrm{h}^{-1}$. In the group with the high eglin dose, $7.7 \mathrm{mg}$. $\mathrm{kg}^{-1} \cdot \mathrm{h}^{-1}$ for $4 \mathrm{~h}, 5$ of 6 animals reached maximum plasma levels of $44.7 \pm 13.6 \mu \mathrm{g} /$ 


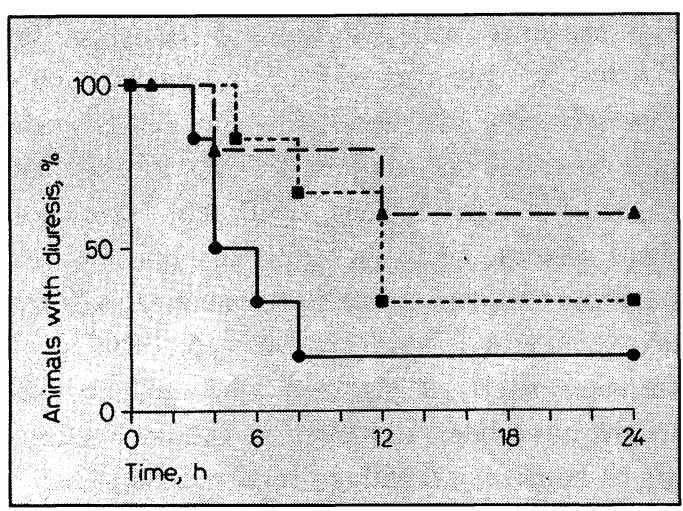

Fig. 5. Cumulative probability plot for the occurence of anuria after $E$. coli and r-eglin $\mathrm{C}$ administration ( $\mathrm{n}=6$ in each group).

E. coli, $3 \cdot 10^{10}$ cells $+\mathrm{NaCl}, 0.9 \%$ (control group) $(\bullet \longrightarrow$ ). E. coli, $3 \cdot 10^{10}$ cells $+\mathrm{r}$-eglin C, $1.9 \mathrm{mg} \cdot \mathrm{kg}^{-1} \cdot \mathrm{h}^{-1}(\mathbf{\Lambda}--\mathbf{\Delta})$. E. coli, $3 \cdot 10^{10}$ cells $+\mathrm{r}$-eglin C, $7.7 \mathrm{mg} \cdot \mathrm{kg}^{-1} \cdot \mathrm{h}^{-1}(\mathbf{( - \cdots - -})$.

$\mathrm{ml}(\hat{=} 5.6 \mu M)$ and 1 animal $100 \mu \mathrm{g} / \mathrm{ml}$. The data of this latter experiment were not used in figure 6. Eglin plasma levels decayed rapidly after the end of the infusion.

\section{Other Parameters}

White blood cell counts uniformly showed a rapid initial decline by $80-90 \%$ with a minimum after $1-6 \mathrm{~h}$ followed by the slow development of leukocytosis in all animals that survived more than $12 \mathrm{~h}$. Details on white blood cells and elastase-inhibitor complex levels in plasma have been reported elsewhere [11]. All animals showed a moderate degree of thrombocytopenia but platelet counts below $100,000 / \mu 1$ were found in 1 case only. The decrease was maximum after $8 \mathrm{~h}(186,000 \pm 71,000 / \mu 1$, i.e. $40 \%$ of $459,000 \pm 124,000 / \mu \mathrm{l}$ before the start of the E. coli infusion). The arterial $\mathrm{pO}_{2}$ of all animals at baseline was $85.2 \pm 8.2 \mathrm{~mm} \mathrm{Hg}$. The majority of animals $(11 / 18)$ experienced severe hypoxemia (decrease in arterial $\mathrm{pO}_{2}$ by

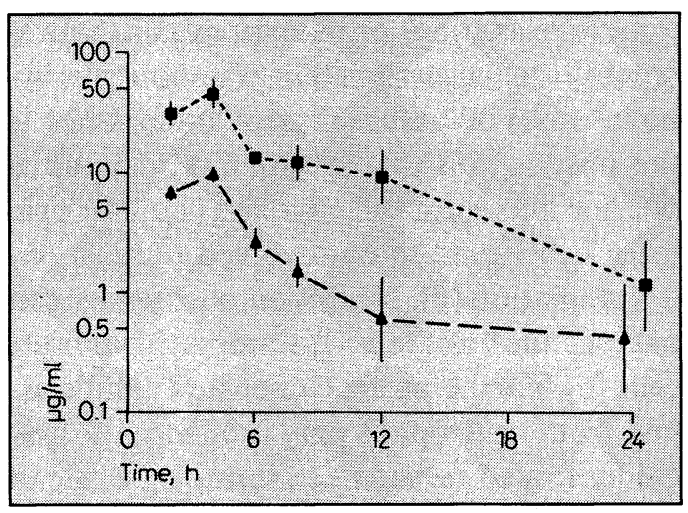

Fig. 6. Eglin $\mathrm{C}$ concentration in plasma after E. coli and r-eglin $\mathrm{C}$ administration. Ordinate: eglin $\mathrm{C}$ concentration in plasma $(\mu \mathrm{g} / \mathrm{ml}$, logarithmic scale, means $\pm \mathrm{SD})(\mathrm{n}=6$ in each group).

E. coli, $3 \cdot 10^{10}$ cells $+\mathrm{r}$-eglin C, $1.9 \mathrm{mg} \cdot \mathrm{kg}^{-1} \cdot \mathrm{h}^{-1}(\Delta--\Delta)$.

E. coli, $3 \cdot 10^{10}$ cells $+\mathrm{r}$-eglin $\mathrm{C}, 7.7 \mathrm{mg} \cdot \mathrm{kg}^{-1} \cdot \mathrm{h}^{-1}(\mathbf{( - - - - \square )}$.

more than $30 \mathrm{~mm} \mathrm{Hg}$ ). The arterial $\mathrm{pCO}_{2}$ of all animals at baseline was $38.2 \pm 4.2 \mathrm{~mm}$ Hg. All but 2 animals (both from the highdose eglin group) developed hypocapnia (arterial $\mathrm{pCO}_{2}$ below $32 \mathrm{~mm} \mathrm{Hg}$ ). The respiratory rate was $26 \pm 11 / \mathrm{min}$ at baseline, and all but 4 animals developed tachypnea (respiratory rate above $40 / \mathrm{min}$ ). Acidosis ( $\mathrm{pH}$ in arterial blood) was slightly less pronounced in the eglin-treated animals.

\section{Discussion}

Treatment of septic pigs with r-eglin $\mathrm{C}$ at two different dosages prevented a fall in blood pressure compared to the nontreated controls. Similarly, in a model of traumatic shock of the rat an improvement of the arterial blood pressure after eglin treatment was noted [3]. These findings may indicate the inhibition of the action of vasoactive mediators (with ensuing vascular smooth 
muscle relaxation) or of compounds that increase vascular permeability (resulting in hypovolemia) or both. Of great importance is the observation that r-eglin $\mathrm{C}$ also inhibits porcine lung mast cell chymase [1]. This protease is believed to be involved in mast cell degranulation [5]. Inhibition of chymase can prevent the release of histamine from mast cells [6]. Furthermore, cathepsin $G$ and elastase from neutrophils may influence the arachidonic acid cascade and thus play a role in vasoregulation [7]. Both enzymes are very rapidly and effectively inhibited by eglin $\mathrm{C}$ [10].

The fall in total protein concentration in plasma was significantly attenuated in the eglin-treated animals. Eglin C apparently protected the septic pigs from developing hypoproteinemia. Moreover, the control animals showed more severe hemoconcentration in their hematocrit values than the eglin-treated animals. This supports the view that an increase in permeability to protein was the primary event leading to subsequent loss of fluid from the vascular bed to the interstitial space. There is ample evidence connecting the action of lysosomal proteinases from neutrophils to increased vascular permeability [12]. Mainly involved are peptide fragments from large proteins such as coagulation and complement factors [13].

The influence of r-eglin $\mathrm{C}$ on hypovolemia and hypotension following $E$. coli septicemia is of great importance for renal function. However, the effect of r-eglin C treatment on the duration of urine production under this condition may also indicate a direct effect of lysosomal proteinases on kidney function. It was shown that neutrophils stimulated in situ by deposited immune complexes digest glomerular basement membrane [14]. Using an enzyme inhibitor, PMN elastase and cathepsin $\mathrm{G}$ were identified as the responsible agents. In 5 of 6 patients suffering from acute renal failure of various origin, elevated plasma levels of the PMN elastase-alpha-1-proteinase inhibitor complex were observed [2]. In blood smears of these patients reduced proteinase activity in granulocytes was found. Hence, lysosomal proteinases such as elastase and cathepsin $G$ might have been involved in the pathogenesis of acute renal failure in these patients.

Although we did not detect statistically significant differences between the two eglintreated groups, it is interesting to note that the animals in the low-dose group had better survival (fig. 1) and diuresis (fig. 5) curves and less hemoconcentration (fig. 4) than those in the high-dose group. We have to consider contamination of the recombinant gene product r-eglin $\mathrm{C}$ with other compounds of bacterial origin as a possible explanation. The batch or r-eglin $\mathrm{C}$ used in our experiment contained less than 5 ppm endotoxin [Schnebli H.P., Basel, Switzerland, personal commun.]. It remains questionable if such a low amount of endotoxin is able to influence the therapeutic effect of eglin $C$ in septicemia in the manner that we suspected. Toxic effects of a first batch of r-eglin C given in a dose of $3.85 \mathrm{mg} \cdot \mathrm{kg}^{-1} \cdot \mathrm{h}^{-1}$ were clearly due to the presence of minute amounts of endotoxin [4].

We conclude that $r$-eglin $C$ at plasma levels between 1 and $5 \mu \mathrm{mol} / 1$ is able to attenuate in vivo the permeability increase and arterial hypotension induced by systemic bacteremia in pigs. This indicates that liberated PMN elastase significantly contributes, among other factors, to the harmful effects precipitated by bacteria in the circulation. r-Eglin C might therefore be a useful drug for. the treatment of septic shock in humans. 


\section{Acknowledgements}

The authors wish to thank Prof. Dr. L. Schweiberer for generous support of this work. Ms. Evi Schaller provided skillful technical assistance. This work was financed in part by a grant from the Deutsche Forschungsgemeinschaft ' (We 1002/2-1). Recombinant eglin C (r-eglin C) was a gift from CibaGeigy AG, Basel, and Plantorgan KG, Bad Zwischenahn.

\section{References}

1 Fink, E.; Nettelbeck, R.; Fritz, H.: Inhibition of mast cell chymase by eglin $\mathrm{C}$ and antileukoprotease (HUSI-I). Biol. Chem. Hoppe-Seyler 367: 567-571 (1986).

2 Heidland, A.; Hörl, W., Heller, N.; Heine, H.; Neumann, S.; Heidbreder, E.: Release of granulocyte neutral proteinases in patients with acute and chronic renal failure. Adv. exp. Med. Biol. 167: 417-431 (1984).

3 Hock, C.E.; Lefer, A.M.: Beneficial effects of a neutral protease inhibitor in traumatic shock. Pharmacol. Res. Commun. 17: 217-226 (1985).

4 Jochum, M.; Welter, H.F.; Wiesinger, H.; Siebeck, M.; Thetter, O.; Fritz, H.: Erste Erfahrungen mit einem klonierten Hemmstoff für lysosomale Elastase und Cathepsin G, dem sog. Eglin des medizinischen Blutegels, beim septischen Schock des Schweines; in Stelzner, Chirurgisches Forum '85, pp. 43-47 (Springer, Berlin 1985).

5 Kido, H.; Fukusen, N.; Katunuma, N.: Chymotrypsin- and trypsin-type serine proteases in rat mast cells. Properties and functions. Archs biochem. Biophys. 239: 436-443 (1985).

6 Kido, H.; Fukusen, N.; Katunuma, N.: Antibody and inhibitor of chymase inhibit histamine release in immunoglobulin E-activated mast cells. Biochem. int. 10: 863-871 (1985).

7 LeRoy, E.C.; Ager, A.; Gordon, J.L.: Effects of neutrophil elastase and other proteases on porcine aortic endothelial prostaglandin $I_{2}$ production, adenine nucleotide release, and responses to vasoactive agents. J. clin. Invest. 74: 1003-1010 (1984).
8 Müller-Esterl, W.: Enzyme-linked Immunosorbent Assay for Aprotinin; in Bergmeyer, Methods of enzymatic analysis, vol. XII, pp. 246-256 (VCH Verlagsgesellschaft, Weinheim 1986).

9 Rink, H.; Liersch, M.; Sieber, P.; Meyer, F.: A large fragment approach to DNA synthesis: total synthesis of a gene for the protease inhibitor eglin $\mathrm{C}$ from the leech Hirudo medicinalis and its expression in E. coli. Nucl. Acids Res. 12: 63696387 (1984).

10 Seemüller, U.; Meier, M.; Ohlsson, K.; Müller, H.P.; Fritz, H.: Isolation and characterisation of a low molecular weight inhibitor (of chymotrypsin and human granulocytic elastase and cathepsin G) from leeches. Hoppe-Seyler's Z. physiol. Chem. 358: 1105-1117 (1977).

11 Siebeck, M.; Hoffmann, H.; Geiger, R.: Granulocyte elastase and white cell count in septic pigs. Prog. Clin. Biol. Res. 236A: 115-118 (1987).

12 Spragg, R.G.; Cochrane, C.G.: Human neutrophil elastase and acute lung injury; in Zapol, Falke, Acute respiratory failure, pp. 379-405 (Dekker, New York 1985).

13 Venge, P.: Polymorphonuclear leukocyte proteases and their effects on complement components and neutrophil function; in Havemenn, Janoff, Neutral proteases of human polymorphonuclear leukocytes, pp. 264-275 (Urban \& Schwarzenberg, Baltimore 1978).

14 Vissers, M.C.M.; Winterbourn, C.C.; Hunt, J.S.: Degradation of glomerular basement membrane by human neutrophils in vitro. Biochim. biophys. Acta 804: 154-160 (1984).

Received: February 8, 1988

Accepted: July 23, 1988

Dr. med. Matthias Siebeck

Chirurgische Klinik Innenstadt

Nussbaumstrasse 2

D-8000 München 2 (FRG) 